Karol Żakowski

Uniwersytet Łódzki

\title{
W cieniu problemów historycznych Narzędzia chińskiej polityki zagranicznej wobec Japonii
}

Japonia pod wieloma względami zajmuje bardzo istotne miejsce w chińskiej dyplomacji. Jest to jedno z najbogatszych mocarstw gospodarczych świata oraz główny sojusznik Stanów Zjednoczonych w regionie Azji Wschodniej. Z jednej strony bliskość geograficzna i podobieństwa kulturowe predestynują Chiny i Japonię do wzajemnej współpracy, z drugiej zaś istnieją liczne czynniki, które utrudniają budowę zaufania w stosunkach między oboma państwami. Nie chodzi tu jedynie o udostępnianie przez Japonię swoich terytoriów dla baz amerykańskich, ale również o nadal nierozwiązany spór terytorialny o wyspy Senkaku/Diaoyu czy problemy historyczne związane z japońskim ekspansjonizmem w czasie II wojny światowej.

Ponieważ utrzymanie wysokiego tempa wzrostu gospodarczego stanowiło priorytet dla borykających się z licznymi problemami społecznymi Chin, głównym celem dyplomacji tego kraju wobec Japonii za prezydentury Hu Jintao było utrzymanie stabilnych relacji, sprzyjających wymianie handlowej i przyciąganiu japońskich inwestycji. Niemniej jednak w sytuacjach kryzysowych ChRL reagowała zdecydowanie, broniąc własnego interesu narodowego za pomocą wszelkich możliwych instrumentów. Nie należy bowiem zapominać, że dalekosiężnym celem dyplomacji chińskiej było zasygnalizowanie, iż to Państwo Środka, a nie Kraj Kwitnącej Wiśni, jest głównym mocarstwem wschodnioazjatyckim, predestynowanym do przywództwa w regionie.

Chiny stosowały wobec Japonii całą paletę różnorodnych narzędzi. Chociaż początkowo były zależne od pomocy gospodarczej władz w Tokio, wraz ze stopniowym przenoszeniem japońskich fabryk do ChRL same uzyskały istotny środek do wywierania presji na Japonię poprzez groźbę wprowadzenia ograniczeń we współpracy gospodarczej z tym krajem. Dyplomacja rządu w Pekinie wobec Kraju Kwitnącej Wiśni obejmowała zarówno elementy soft power, np. rozwijanie wymiany kulturowej i pielęgnowanie kontaktów z politykami japońskich partii rządzących, jak i hard power, chociażby niestronienie od prowokacyjnych naruszeń japońskich wód terytorialnych przez okręty wojenne. Cechą charakterystyczną 
polityki Chin wobec Japonii były jednak narzędzia ideologiczno-kulturowe. W chwili zagrożenia interesu narodowego ChRL nie wahała się użyć „karty historycznej”, dając do zrozumienia, że Japonii „wolno mniej” na arenie międzynarodowej z powodu trudnej przeszłości tego kraju.

\section{Narzędzia ideologiczno-kulturowe}

Chiny i Japonia należą do tej samej, sinicznej strefy kulturowej. Liczne elementy kultury japońskiej są bezpośrednimi zapożyczeniami z kultury chińskiej. Kraj Kwitnącej Wiśni zawdzięcza Państwu Środka pismo, wiele elementów sztuki i architektury, filozofię konfucjańską, jak i starożytne wzorce organizacji państwa. Także powstały w Indiach buddyzm przybył do Japonii poprzez Chiny i Koreę. Chociaż pod względem kulturowym i cywilizacyjnym Japonia wiele zawdzięcza Chinom, pod względem rozwoju gospodarczego i technologicznego przewyższyła swojego „nauczyciela” dzięki wprowadzeniu pod koniec XIX w. reform na wzór europejski. Kraj Kwitnącej Wiśni, rosnący w siłę w epoce Meiji (1868-1912), stoczył z Państwem Środka zwycięską wojnę w latach 1894-1895, zabierając mu Tajwan. Również w kolejnych dziesięcioleciach japońska ekspansja odbywała się głównie kosztem Chin. W 1931 r. Japonia zdobyła Mandżurię, tworząc tam podporządkowane sobie państwo. Do następnego otwartego konfliktu doszło w latach 1937-1945. W czasie II wojny światowej Japończycy podbili niemal całe wschodnie wybrzeże Chin, dopuszczając się na okupowanych terenach licznych zbrodni. Najbardziej znaną z nich była masakra nankińska z grudnia 1937 r., w której zginęło przynajmniej kilkadziesiąt tysięcy Chińczyków. Bezpośrednio po utworzeniu ChRL przywództwo KPCh stroniło od wykorzystywania „karty historycznej" w relacjach z Japonią. Władzom w Pekinie zależało na nawiązaniu oficjalnych stosunków dyplomatycznych $\mathrm{z}$ rządem w Tokio, podkreślały więc, że zbrodnie wojenne były dziełem garstki japońskich militarystów, a nie całego narodu. W przeciwieństwie do Związku Radzieckiego, Chiny dość dobrze traktowały jeńców japońskich i szybko pozwoliły im powrócić do ojczyzny. Na dodatek w latach 50. XX w. ChRL wypuściła $\mathrm{z}$ więzień zdecydowaną większość japońskich zbrodniarzy wojennych ${ }^{1}$. Kiedy zaś w 1972 r. dokonano normalizacji chińsko-japońskich stosunków dyplomatycznych, władze w Pekinie zgodziły się na rezygnację z odszkodowań wojennych.

Do pierwszych głośnych incydentów związanych z problemami historycznymi na linii Tokio-Pekin doszło dopiero w latach 80. XX w. W 1982 r. prasa nagłośniła fakt, że japońskie Ministerstwo Edukacji poleciło autorom niektó-

1 K. Żakowski, Antyjapońskie oblicze nacjonalizmu chińskiego, [w:] Fenomen Chin. Wybrane problemy polityki wewnętrznej i zagranicznej Chińskiej Republiki Ludowej, pod red. M. Pietrasiak, Wydawnictwo Uniwersytetu Łódzkiego, Łódź 2007, s. 153. 
rych z podręczników do historii zamianę sformułowań, które odnosiły się do niechlubnej przeszłości kraju na łagodniejsze eufemizmy - np. wyraz ,inwazja” (shinryaku), użyty w kontekście najazdu na Chiny, miał być zastąpiony przez „posuwanie się” (shinshutsu)2. Wywołało to ostre protesty ze strony Chin i Korei Południowej. Jeszcze większą falę demonstracji antyjapońskich sprowokowała oficjalna wizyta premiera Nakasone Yasuhiro w świątyni Yasukuni ${ }^{3}$ w 40. rocznicę kapitulacji Japonii 15 sierpnia 1985 r. Ponieważ Yasukuni jest poświęcona Japończykom, którzy polegli za ojczyznę, od 1978 r. także zbrodniarzom wojennym klasy A skazanym przez Trybunał Tokijski, nic dziwnego, że wydarzenie to wywołało oddźwięk za granicą. Nie jest natomiast jasne, dlaczego władze w Pekinie zgłosiły protest wobec wizyt japońskich premierów w świątyni dopiero w $1985 \mathrm{r}$. Raczej nie dlatego, że była to pierwsza wizyta oficjalna - od 1985 roku Chiny zaczęły się sprzeciwiać odwiedzinom w Yasukuni również w charakterze prywatnym, choć wcześniej nie czyniły z tym problemów. W każdym razie incydent ten sygnalizował zmianę dotychczasowej biernej postawy ChRL w sprawie pamięci historycznej. Peter Hays Gries podkreśla, że oficjalny dyskurs na temat wojny z Japonią ewoluował z wizerunku „Chin jako zwycięzcy” ku obrazowi „Chin jako ofiary"4. Było to związane z potrzebą legitymizacji władzy KPCh za pomocą innych środków niż ideologia komunistyczna, która wraz z reformami wolnorynkowymi coraz mniej przystawała do rzeczywistości.

Od lat 90. ubiegłego wieku problemy historyczne stały się już jednym z głównych czynników wpływających na atmosferę w relacjach chińsko-japońskich. Do kulminacji napięcia doszło w 1996 r., gdy prowokacyjne zachowanie japońskich nacjonalistów na spornych z ChRL wyspach Senkaku/Diaoyu ${ }^{5}$ skłoniło chińskich aktywistów do przygotowania serii wypraw na ten bezludny archipelag. W trakcie jednej z nich utonął organizator rejsu, David Chan. Na dodatek równolegle Hashimoto Ryūtarō, jako pierwszy japoński premier od 1985 r., odwiedził świątynię

2 C. Rose, The Textbook Issue: Domestic Sources of Japan's Foreign Policy, „Japan Forum” 1999, vol. 11, no. 2, s. 205-207.

3 Świątynia Yasukuni została zbudowana w 1869 r. (pod obecną nazwą funkcjonuje od 1879 r.) jako miejsce oddawania hołdu Japończykom, którzy zginęli w służbie cesarzowi i ojczyźnie. Z czasem stała się jednym z głównych symboli nacjonalistycznych w kraju. Szerzej na ten temat: Takahashi Tetsuya, Yasukuni Mondai [Problem Yasukuni], Chikuma Shobō, Tokio 2005.

${ }_{4}$ P.H. Gries, China's New Nationalism. Pride, Politics, and Diplomacy, University of California Press, Berkeley-Los Angeles-London 2004, s. 69-85.

5 Japonia utrzymuje, iż dokonała inkorporacji archipelagu Senkaku/Diaoyu jako terra nullius w 1895 r. Republika Chińska na Tajwanie i ChRL zgłosiły pretensje do wysp dopiero w 1970 r., po odkryciu w ich okolicy pokaźnych złóż surowców energetycznych. Swoje stanowisko strona chińska dokumentuje dowodami historycznymi na to, że wyspy Senkaku/Diaoyu były od wieków wykorzystywane przez Chińczyków jako obszar rybacki, punkt nawigacyjny oraz element linii obrony wybrzeża. Szerzej na ten temat: Unryu Suganuma, Sovereign Rights and Territorial Space in Sino-Japanese Relations. Irredentism and the Diaoyu/Senkaku Islands, Association for Asian Studies, University of Hawai'i Press, Honolulu 2000. 
Yasukuni. Wydarzenia te wywołały falę masowych demonstracji antyjapońskich zarówno w ChRL, jak i na Tajwanie i w Hongkongu. Sytuacja uległa dalszej eskalacji na początku XXI w. W dużym stopniu przyczynił się do tego Koizumi Jun'ichirō, który jako premier Japonii w latach 2001-2006, corocznie odwiedzał świątynię Yasukuni.

Jednym z powodów nagłego wzrostu nienawiści wobec Japończyków było rozpoczęcie w ChRL na początku lat 90 . XX w. kampanii edukacji patriotycznej. Poprzez budowę nowych miejsc pamięci o zbrodniach japońskich z czasów II wojny światowej władze KPCh chciały się upewnić, że społeczna uwaga skieruje się ku problemom zewnętrznym, a nie ku niedoskonałościom reżimu ${ }^{6}$. Był to jednak „miecz obosieczny”. Rosnąca w siłę chińska klasa średnia, żywiołowo wymieniająca opinie za pomocą Internetu, stała się trudna do kontrolowania, zaś nadmierna eskalacja napięcia $\mathrm{w}$ stosunkach $\mathrm{z}$ Japonią mogła zaszkodzić interesom ChRL. Władze w Pekinie zazwyczaj starały się wyciszać protesty uliczne, ale jednocześnie musiały demonstrować nieugiętość wobec Japonii, aby społeczne niezadowolenie nie obróciło się przeciw przywództwu KPCh.

Nie jest łatwo odróżnić, kiedy twarda postawa ChRL wobec Japonii w kwestiach historycznych była spowodowana oddolnymi antyjapońskimi protestami, a kiedy chęcią instrumentalnego posłużenia się „kartą historyczną” przez rząd w Pekinie. Niemniej jednak w wielu wypadkach zbieżność pomiędzy chińskim interesem narodowym a nasileniem krytyki ,japońskiego militaryzmu” może wskazywać na to, że czasami problemy historyczne stanowiły dla ChRL wygodny pretekst do wywierania presji na władze w Tokio w sprawach niezwiązanych bezpośrednio z trudną przeszłością obu krajów. Jako przykład można podać kwestię przyznania Japonii stałego miejsca w Radzie Bezpieczeństwa ONZ, negocjacji w sprawie wspólnej eksploatacji złóż naturalnych Morza Wschodniochińskiego oraz incydentu wywołanego zderzeniem chińskiego kutra z japońskim okrętem patrolowym w pobliżu wysp Senkaku/Diaoyu.

W marcu 2005 r. sekretarz generalny ONZ Kofi Annan ogłosił, że Japonia jest na dobrej drodze do uzyskania stałego miejsca w Radzie Bezpieczeństwa ONZ. Wiadomość ta sprowokowała falę gwałtownych demonstracji antyjapońskich w całych Chinach. Tłum nie tylko obrzucił kamieniami japońską ambasadę w Pekinie i konsulat generalny w Szanghaju, ale także zaczął atakować japońskich turystów i pustoszyć japońskie restauracje. Manifestanci powoływali się na problemy historyczne jako na dowód, że Japonia nie zasługuje na stałe miejsce w Radzie Bezpieczeństwa7. Chińscy nacjonaliści zorganizowali masową akcję

${ }^{6}$ K. Żakowski, Antyjapońskie..., s. 154-156.

7 Tabata Mitsunaga, Hannichi demo wa minzokushugi ka - Ikutsuka no ronten seiri [Czy demonstracje antyjapońskie są nacjonalizmem? Uporządkowanie kilku punktów dyskusji], [w:] Nitchū sōgo rikai no tame no Chūgoku nashonarizumu to media bunseki [Analiza chińskich mediów i nacjonalizmu w celu wzajemnego porozumienia japońsko-chińskiego] pod red. Takaia Kiyoshiego, Akashi Shoten, Tokio 2005, s. 89-90. 
zbierania w Internecie podpisów pod petycją w tej sprawie. O tym, jak wielką popularnością cieszyła się owa inicjatywa, świadczy fakt, że do końca kwietnia 2005 r. zgromadzono aż $41 \mathrm{mln}$ podpisów ${ }^{8}$. Skala protestów sprawiła, że rząd w Pekinie musiał przyjąć twarde stanowisko wobec Japonii.

Z drugiej strony wiele wskazuje na to, że demonstracje antyjapońskie mogły się rozprzestrzeniać tak szybko dzięki cichemu wsparciu ze strony przywództwa $\mathrm{KPCh}^{9}$. Władzom w Pekinie nigdy nie zależało na wzmocnieniu pozycji Japonii w Radzie Bezpieczeństwa, zaś manifestacje uliczne dawały idealny pretekst do odłożenia reformy ONZ na później ${ }^{10}$. W dniu 24 marca 2005 r. Liu Jianchao z chińskiego Ministerstwa Spraw Zagranicznych zauważył, że zbiórka podpisów przeciwko japońskim staraniom o stałe miejsce w Radzie Bezpieczeństwa nie była kwestią uczuć antyjapońskich, ale ,żądaniem wobec Japonii, aby przyjęła właściwą i odpowiedzialną postawę w kwestii problemów historycznych" ${ }^{11}$. Co więcej, państwowa agencja prasowa Xinhua opublikowała list do Kofiego Annana napisany przez Tong Zenga, jednego z przywódców ruchu antyjapońskiego $^{12}$. Fakt, że oficjalne media dopuściły do głosu działacza, który zazwyczaj był traktowany jako ,element wywrotowy”, wskazuje na rządowe poparcie dla manifestacji. Zresztą sam premier Wen Jiabao w czasie wizyty w New Delhi w połowie kwietnia 2005 r. zauważył, że „tylko kraj, który szanuje historię i czuje się za nią odpowiedzialny, może wziąć większą odpowiedzialność w społeczności międzynarodowej"13. W ten sposób ukazał różnicę pomiędzy Japonią a Indiami, które uzyskały od ChRL wstępną obietnicę wsparcia starań o stałe miejsce w Radzie Bezpieczeństwa. Chińskie władze odrzuciły japońskie żądania przeprosin i odszkodowań za straty wyrządzone przez demonstrujące tłumy, zrzucając winę na władze w Tokio, które miały sprowokować demonstracje, szerząc niewłaściwą wizję historii ${ }^{14}$. Dopiero gdy protesty osiągnęły niepokojącą skalę, rząd w Pekinie zdecydował się na ich wyciszenie.

${ }^{8}$ Liu Zhiming, Nitchū komyunikēshon gyappu to jōhō hasshin [Przepaść w komunikacji japońsko-chińskiej a transmisja informacji], [w:] Nitchū sōgo rikai..., s. 125-126.

9 Seki Hei, „Nitchū yūkō” wa Nihon o horobosu! Rekishi ga oshieru ,,datsu Chūgoku” no hōsoku [„Przyjaźń japońsko-chińska” zniszczy Japonię! Zasada „porzucenia Chin” uczona przez historię], Kōdansha, Tokio 2005, s. 134-135.

10 Yomiuri Shinbun Seijibu, Gaikō o kenka ni shita otoko. Koizumi gaikō 2000 nichi no shinjitsu [Mężczyzna, który prowadził kłótnie w sprawach dyplomacji. Prawda o 2000 dni dyplomacji Koizumiego], Shinchōsha, Tokio 2006, s. 281.

${ }_{11}$ Foreign Ministry Spokesman Liu Jianchao 's Press Conference on 24 March 2005, http://big5. fmprc.gov.cn/gate/big5/www.mfa.gov.cn/eng/xwfw/s2510/2511/t188945.htm [dostęp 10.07.2010].

12 Seki Hei, ,Nitchū yūkō”..., s. 136.

13 Yomiuri Shinbun Seijibu, Gaikō o kenka ni shita otoko..., s. 281.

14 Ōnuki Hiroyuki, Chūgoku ni okeru kokka to shakai no henshitsu no hōkō ni kansuru kōsatsu - sono 6 [Analiza kierunku zmian w państwie i społeczeństwie Chin, cz. 6], „Reitaku Journal of Interdisciplinary Studies", vol. 14, no. 2, s. 101. 
Innym przykładem instrumentalnego wykorzystania „karty historycznej” przez Chiny mogą być negocjacje dotyczące wspólnej eksploatacji złóż naturalnych Morza Wschodniochińskiego. Chińsko-japoński spór o delimitację wód akwenu rozpoczął się na przełomie lat 60. i 70. XX w., po wykryciu tam olbrzymich złóż surowców energetycznych. Zgodnie ze stanowiskiem japońskim granica pomiędzy wyłącznymi strefami ekonomicznymi powinna przebiegać pośrodku morza - wzdłuż mediany, czyli linii równo oddalonej od wybrzeży obu krajów. Z kolei rząd Chin rości sobie prawo do całego szelfu kontynentalnego, aż po Rów Okinawy, położony blisko należących do Japonii wysp Riukiu. Spór uległ eskalacji w sierpniu 2003 r., kiedy ChRL rozpoczęła budowę platformy wiertniczej Chunxiao/Shirakaba, położonej zaledwie kilka kilometrów od linii uważanej przez Japonię za granicę jej wyłącznej strefy ekonomicznej. Japonia wielokrotnie wzywała rząd w Pekinie do podzielenia się wynikami badań dna morskiego, aby wyjaśnić, czy inwestycja nie spowoduje wysysania złóż z japońskiej strony mediany, jednak rząd chiński odmówił.

Pierwsza runda rozmów w sprawie wspólnej eksploatacji złóż naturalnych Morza Wschodniochińskiego odbyła się w październiku 2004 r., ale nie przyniosła żadnych rezultatów ${ }^{15}$. W spór szybko zaangażowali się chińscy nacjonaliści. Kiedy 7 lipca 2004 r. władze w Tokio ogłosiły zamiar przeprowadzenia własnych badań geologicznych dna morskiego, działacze antyjapońscy zinterpretowali wybór tej daty jako chęć upokorzenia ich ojczyzny - była to rocznica japońskiej inwazji na Chiny w 1937 r. We wrześniu 2004 r. rozpoczęli nawet akcję zbierania podpisów pod petycją, w której żądali od władz w Pekinie budowy lotniskowca w celu obrony Morza Wschodniochińskiego ${ }^{16}$. Chociaż były to inicjatywy oddolne, współgrały z interesem Chin. Dopóki Chiny eksploatowały złoże, a Japonia nie, zachowanie status quo działało na korzyść władz ChRL. Problemy historyczne stanowiły idealny pretekst do przekładania rozmów. W trakcie negocjacji we wrześniu 2005 r. Japonia przedstawiła propozycję wspólnej eksploatacji złóż akwenu, ale przywództwo KPCh odrzuciło ofertę. Po piątej wizycie premiera Koizumiego w świątyni Yasukuni w październiku 2005 r. Chiny zawiesiły wszelkie spotkania na wysokim szczeblu z Japonią, przez co negocjacje dotyczące eksploatacji surowców Morza Wschodniochińskiego zostały odłożone do marca 2006 r. ${ }^{17}$

Jak już zostało wcześniej wspomniane, także spór terytorialny o wyspy Senkaku/Diaoyu stał się nierozerwalnie związany z problematyką pamięci historycznej. W oczach chińskich nacjonalistów ten bezludny archipelag jest niczym

15 Uchiyama Yū, Koizumi seiken [Rządy Koizumiego], Chūō Kōron Shinsha, Tokio 2007, s. 142.

16 Yinan He, History, Chinese Nationalism and the Emerging Sino-Japanese Conflict, ,Journal of Contemporary China" 2007, vol. 16, no. 50, s. 15-16.

${ }_{17}$ M.J. Valencia, The East China Sea Dispute: Context, Claims, Issues, and Possible Solutions, „Asian Perspective” 2007, vol. 31, no. 1, s. 132-134. 
innym, jak ostatnim chińskim terytorium znajdującym się pod japońską okupacją. Władze w Pekinie starały się tłumić w zarodku pomysły organizacji przez chińskich aktywistów wypraw na wyspy, jednak w związku z prowokacyjnymi wizytami premiera Koizumiego w świątyni Yasukuni na początku XXI w. zaczęły tolerować oddolne inicjatywy w tej sprawie. Jak podkreśla Shimizu Yoshikazu, bez cichego wsparcia ze strony KPCh byłoby nie do pomyślenia, by w grudniu 2003 r. oficjalnie powstała Chińska Pozarządowa Federacja Obrony Wysp Diaoyu (Zhongguo Minjian Bao Diao Lianhehui) ${ }^{18}$. Przyzwolenie władz na działalność antyjapońskich patriotów doprowadziło do incydentu w marcu 2004 r., kiedy siedmiu chińskim działaczom udało się wylądować na jednej z wysp, za co zostali czasowo zatrzymani przez służby japońskie. Aby nie dopuścić do podobnych wydarzeń, władze KPCh poddały odtąd ściślejszej kontroli środowiska działaczy patriotycznych ${ }^{19}$.

Środki ostrożności nie zapobiegły jednak przypadkowym incydentom na Morzu Wschodniochińskim. W dniu 7 września 2010 r. w pobliżu wysp Senkaku/ Diaoyu doszło do zderzenia pomiędzy chińskim kutrem rybackim a japońskim okrętem patrolowym. Japońskie służby aresztowały kapitana kutra, oskarżając go o naruszenie japońskich wód oraz sprowokowanie wypadku (później wyszło na jaw, że to chiński kuter staranował japoński okręt, a nie odwrotnie, jak utrzymywała strona chińska). Incydent doprowadził do nagłego wzrostu napięcia w relacjach bilateralnych. Podobnie jak w 2005 r., przez ChRL przetoczyła się fala żywiołowych protestów antyjapońskich.

Chociaż niekontrolowane demonstracje budziły niepokój wśród przywódców KPCh, stanowiły również skuteczny środek nacisku na rząd w Tokio. Władze w Pekinie zażądały natychmiastowego uwolnienia kapitana kutra - bierna postawa w tej sprawie podważałaby wszakże chińskie roszczenia do spornego archipelagu. Chiny przyjęły bardzo twarde stanowisko wobec Japonii, zawieszając z nią wymianę kulturową, a nawet odmawiając spotkań na szczycie. Nawet po ekstradycji chińskiego kapitana do ChRL 24 września 2010 r. liderzy KPCh nie spuścili $\mathrm{z}$ tonu, żądając oficjalnych przeprosin i odszkodowania za zniszczony kuter. Przez cały październik 2010 r. w Chinach organizowane były kolejne demonstracje antyjapońskie. Sprawa przycichła dopiero po spotkaniu przewodniczącego ChRL Hu Jintao z japońskim premierem Kanem Naoto na szczycie APEC w Jokohamie $\mathrm{w}$ listopadzie $2010 \mathrm{r}^{20}$

18 Shimizu Yoshikazu, ,, Chūgoku mondai” no kakushin [Rdzeń „,problemu chińskiego”], Chikuma Shobō, Tokio 2009, s. 33.

${ }_{19}$ K. Żakowski, Kryzys w relacjach chińsko-japońskich $w$ zwiazku ze sporem o wyspy Senkaku/Diaoyutai, [w:] Wspótczesna Azja Wschodnia. Wybrane zagadnienia, pod red. K. Żakowskiego, Zakład Azji Wschodniej UŁ, Łódź 2011, s. 135, http://www.wsmip.uni.lodz.pl/jednostki/strona_zakladu_azji/Wspolczesna_Azja_Wschodnia.pdf [dostęp 18.12.2011].

20 Ibidem, s. 136-138. 
Do podobnego kryzysu doszło jednak już dwa lata później po wylądowaniu na archipelagu Senkaku/Diaoyu grupy działaczy z Hongkongu 15 sierpnia 2012 r. Tym razem japoński rząd bardzo szybko dokonał ekstradycji aktywistów do Chin, jednak z powodu serii wypraw na sporne wyspy środowisk nacjonalistycznych z obu krajów nie udało się uniknąć eskalacji sporu. Władze w Pekinie ostro skrytykowały zwłaszcza decyzję o zakupie przez Japonię trzech wysp archipelagu od prywatnych właścicieli, podjętą 10 września 2012 r. Żądając jej cofnięcia, rząd ChRL niezwykle nasilił retorykę antyjapońską w środkach masowego przekazu. Wiele wskazuje na to, że władze w Pekinie dały ciche przyzwolenie dla manifestacji. Na przykład 13 września 2012 r. rzecznik prasowy chińskiego Ministerstwa Spraw Zagranicznych Hong Lei stwierdził, iż „każdy w Chinach jest oburzony niewłaściwym zachowaniem strony japońskiej i zdecydowanie popiera słuszne żądania oraz mocne środki zastosowane przez rząd chiński” ${ }^{21}$. Przez całe Chiny przetoczyła się wówczas fala gwałtownych antyjapońskich demonstracji, podczas których dochodziło do napaści na japońskich turystów czy restauratorów, niszczenia japońskich samochodów, a także demolowania i podpalania japońskich sklepów i fabryk. Jej kulminacja nastąpiła 18 września 2012 r., w rocznicę japońskiej inwazji na Mandżurię.

Jak widać, nacjonalizm i problemy historyczne w poważnym stopniu wpływają na atmosferę $\mathrm{w}$ relacjach chińsko-japońskich. $\mathrm{Z}$ powodu rozbudzonych uczuć patriotycznych, zwłaszcza wśród młodych Chińczyków, nawet błahy incydent może przemienić się w poważny kryzys dyplomatyczny. O ile protesty antyjapońskie zazwyczaj zaczynały się jako oddolne inicjatywy środowisk nacjonalistycznych, skala, do której urosły, często wskazywała na ciche poparcie ze strony władz w Pekinie. Niechęć do zbyt szybkiego tłumienia tego typu ruchów wynikała po części z obawy skierowania przez protestujących ostrza krytyki przeciw rządowi, jednak w pewnym stopniu była również podyktowana pragnieniem instrumentalnego wykorzystania nastrojów społecznych do wywarcia presji na władze w Tokio, bądź też „badania”, na ile tego typu narzędzia mogą być skuteczne w relacjach z Japonią.

O ile posługiwanie się kartą historyczną było w pewnym stopniu skuteczne w wywieraniu nacisku na Japonię, o tyle jednocześnie osłabiało efektywność chińskiej soft-power wobec tego kraju. Chiny prowadziły bardzo intensywną dyplomację publiczną w Japonii. Od 2005 r. do początku 2013 r. Państwo Środka otworzyło w Kraju Kwitnącej Wiśni aż 19 Instytutów Konfucjusza - najwięcej w Azji Wschodniej po Tajlandii (23) i Korei Południowej (21) 22. Zgodnie

${ }_{21} 2012$ nian 9 yue 13 ri Waijiaobu fayanren Hong Lei zhuchi lixing jizhehui [Regularna konferencja prasowa rzecznika prasowego Ministerstwa Spraw Zagranicznych z 13 września 2012 r.], http://www.fmprc.gov.cn/chn/gxh/tyb/fyrbt/jzhsl/t969139.htm [dostęp 27.10.2012].

${ }_{22}$ Quanqiu Kongzi Xueyuan [Instytuty Konfucjusza na świecie], http://cimap.chinese.cn/ [dostęp 16.01.2013]. 
jednak z badaniami opinii publicznej, prowadzonymi w Japonii przez Biuro Gabinetu, w latach 2005-2012 odsetek Japończyków deklarujących sympatię wobec Chin spadł z 32,4\% do zaledwie 18\% ${ }^{23}$. Trudno się dziwić - niezależnie od tego, jak bardzo Państwo Środka nie promowałoby swojej bogatej kultury, efekty dyplomacji publicznej w Kraju Kwitnącej Wiśni będą znikome dopóty, dopóki Japończycy będą oglądać w telewizji obrazy nienawiści, jaką darzą ich Chińczycy. W takich warunkach budowanie pozytywnego wizerunku ChRL jest niemożliwe.

\section{Narzędzia gospodarcze}

Wykorzystanie narzędzi ideologiczno-kulturowych przez Chiny niejednokrotnie szło $\mathrm{w}$ parze $\mathrm{z}$ wywieraniem nacisku za pomocą instrumentów gospodarczych. Chociaż stosunki chińsko-japońskie za rządów Koizumiego często opisywano jako ,zimne w sferze polityki, ale gorące pod względem ekonomicznym" (chin. zhengleng jingre, jap. seirei keinetsu), problemy historyczne z czasem zaczęły wpływać również na pozycję japońskich firm w ChRL. Nie chodzi tu jedynie o oddolne akcje bojkotu japońskich produktów, które stały się niemal obowiązkowym elementem demonstracji antyjapońskich, ale również o świadome wykorzystywanie przez rząd w Pekinie narzędzi gospodarczych w celu wywarcia presji na Japonię.

Chociaż w 2002 r. rząd chiński wstępnie wybrał japońską ofertę na budowę szybkiej kolei pomiędzy Pekinem i Szanghajem, z powodu wizyt premiera Koizumiego w świątyni Yasukuni zaczął odkładać ostateczną decyzję w tej sprawie. Jednocześnie strona chińska coraz wyraźniej zaznaczała w rozmowach z władzami w Tokio, iż realizacja inwestycji zależy przede wszystkim od właściwej postawy Japonii wobec problemów historycznych. Chinom zależało na zdążeniu z budową szybkiej kolei do Igrzysk Olimpijskich w Pekinie w 2008 r., jednak musiały także brać pod uwagę nastroje społeczne. Przykładowo w lipcu 2003 r. jedna z nacjonalistycznych chińskich organizacji, Sojusz Patriotów (Aiguozhe Tongmeng), zorganizowała akcję zbierania podpisów pod internetową petycją przeciwko wybraniu japońskiej oferty ${ }^{24}$. W celu wywarcia presji na władze w Tokio ambasador Chin w Japonii Wu Dawei skłonił w sierpniu 2004 r. do rozmowy

${ }^{23}$ Chügoku ni tai suru shinkinkan [Sympatia wobec Chin], http://www8.cao.go.jp/survey/h24/ h24-gaiko/zh/z10.html [dostęp 16.01.2013].

${ }^{24}$ Hong Junhao, Wangluo yulun yu Zhongguo de waijiao juece [Opinia publiczna w Internecie a chińska dyplomacja], [w:] Zhongguo waijiao juece: Kaifang yu duoyuan de shehui yinsu fenxi [Dyplomacja Chin: Analiza otwarcia i różnorodnych czynników społecznych] pod red. Hao Yufana i Lin Su, Shehui Kexue Wenxian Chubanshe, Pekin 2007, s. 129. 
z Koizumim najbardziej wpływowych reprezentantów japońskiego świata biznesu: prezesa Japońskiej Federacji Organizacji Gospodarczych (Nippon Keidanren) Okudę Hiroshiego oraz honorowego prezesa tej organizacji, Imaia Takashiego. Nawet oni nie byli jednak w stanie przekonać premiera do zmiany zdania w sprawie wizyt w kontrowersyjnej świątyni ${ }^{25}$.

Chiny wykorzystywały narzędzia gospodarcze do wywarcia presji na Japonię także po ustąpieniu Koizumiego ze stanowiska premiera. We wrześniu 2010 r., w czasie kryzysu wywołanego przez opisany wcześniej incydent na Morzu Wschodniochińskim, ChRL wstrzymała eksport do Japonii metali ziem rzadkich, niezbędnych do produkcji wielu komponentów elektronicznych, w tym silników samochodów hybrydowych. Chociaż jedną z przyczyn tej decyzji były czynniki obiektywne - gwałtownie rozwijające się Chiny przeznaczają na eksport coraz mniej surowców, gdyż są one potrzebne w kraju - data tego zdarzenia zdaje się jednoznacznie wskazywać na chęć wywarcia presji na władze w Tokio w celu zmuszenia strony japońskiej do wypuszczenia przetrzymywanego kapitana kutra. ChRL jest największym dostarczycielem metali ziem rzadkich - przypada na nią $36 \%$ światowych złóż i 97\% globalnego wydobycia ${ }^{26}$. Japoński przemysł w aż 90\% sprowadza metale ziem rzadkich z Chin, więc decyzja o wstrzymaniu ich eksportu wywołała duże zaniepokojenie w Japonii, zmuszając rząd w Tokio do rozpoczęcia dyskusji na temat dywersyfikacji źródeł dostaw tych surowców ${ }^{27}$. Incydent ten pokazał, że coraz potężniejsze Chiny nie stronią już od używania narzędzi ekonomicznych w polityce zagranicznej.

Posługiwanie się przez ChRL instrumentami gospodarczymi może być skuteczne dzięki rosnącemu uzależnieniu japońskich firm od handlu z ChRL oraz od inwestycji w tym kraju. W 2010 r. wartość handlu między oboma państwami (nie licząc Hongkongu) wyniosła w sumie 301,9 mld USD i wzrosła w porównaniu z poprzednim rokiem o 30\%. Eksport do Chin osiągnął wartość 149,1 mld USD, zaś import 152,8 mld USD. W ten sposób czwarty rok z rzędu Chiny okazały się dla Japonii największym partnerem handlowym, wyraźnie wyprzedzając pod tym względem Stany Zjednoczone (wartość handlu japońsko-amerykańskiego wynosiła w sumie 185,5 mld USD). Z kolei dla ChRL Japonia była drugim po USA partnerem handlowym, przy czym zajmowała pierwsze miejsce pod względem

25 Yomiuri Shinbun Seijibu, Gaikō o kenka ni shita otoko..., s. 256-257.

${ }_{26}$ Marukawa Tomoo, Tekuno nashonarizumu no shōtotsu - Reaāsu o meguru nitchū kankei [Zderzenie techno-nacjonalizmów - Sprawa metali ziem rzadkich w relacjach japońsko-chińskich], [w:] Chūgoku wa, ima [Chiny obecnie] pod red. Kokubun Ryōsei, Iwanami Shoten, Tokio 2011, s. $173-177$.

${ }^{27}$ Hosei yosan. Seifu, 11 gatsu shojun seiritsu mezasu. „Nejire” shingi ni okure mo [Nowelizacja budżetu. Rząd dąży do uchwalenia na początku listopada. Możliwe też opóźnienie w czasie debaty w „wykręconym parlamencie”], „Yomiuri Shinbun”, 2.10.2010, s. 11. 
importu. Wartość japońskich bezpośrednich inwestycji zagranicznych w Chinach w 2010 r. wyniosła 4,24 mld USD i wzrosła w porównaniu z rokiem poprzednim o 3\%. Dla porównania, wartość chińskich inwestycji w Japonii osiągnęła w tym samym czasie wartość zaledwie 84,1 mln USD i wzrosła w porównaniu z rokiem poprzednim o 43,5\%. W 2009 r. w ChRL działalność prowadziły aż 22263 przedsiębiorstwa z Japonii, co stanowiło 7,8\% wszystkich zagranicznych firm w Chinach. Japonię pod tym względem wyprzedzały jedynie Stany Zjednoczone (26 tys. przedsiębiorstw) ${ }^{28}$.

Równocześnie z zacieśnianiem bilateralnej wymiany handlowej malało uzależnienie Chin od pomocy gospodarczej z Japonii. Kiedy Państwo Środka wchodziło na drogę reform pod koniec lat 70. XX w., bardzo ważną rolę w jego rozwoju odgrywała oficjalna pomoc rozwojowa (Official Development Assistance - ODA, jap. seifu kaihatsu enjo), zwłaszcza w postaci niskooprocentowanych pożyczek w jenach, otrzymywana od Japonii od 1979 r. Wartość pomocy rozwojowej przekazanej Chinom przez władze w Tokio w latach 1979-2005 ocenia się w sumie na 3,4 bln jenów. Była ona przeznaczana głównie na rozbudowę infrastruktury - dróg, lotnisk, portów czy elektrowni ${ }^{29}$. Od lat 90. XX w. wśród japońskich polityków narastało jednak niezadowolenie z faktu, że ODA nie jest skuteczna w promocji pozytywnego wizerunku Japonii wśród Chińczyków. W marcu 2005 r., podczas gdy w Chinach trwały masowe demonstracje antyjapońskie, minister spraw zagranicznych Japonii Machimura Nobutaka przekazał władzom w Pekinie zamiar zakończenia pożyczek w jenach w ramach ODA w chwili otwarcia Igrzysk Olimpijskich w Pekinie w sierpniu 2008 r. ${ }^{30} \mathrm{~W}$ ten sposób rząd w Tokio pozbawił się istotnego narzędzia wywierania presji na ChRL. Odtąd władze w Pekinie nie musiały obawiać się gróźb wstrzymania przez Japonię pomocy rozwojowej, co dało im większą swobodę w wykorzystywaniu własnych atutów gospodarczych w kontaktach z rządem w Tokio.

Jednocześnie wysokie tempo wzrostu gospodarczego umacniało pozycję ChRL na arenie międzynarodowej. W 2010 r. Chiny wyprzedziły Japonię pod względem PKB, stając się drugą po Stanach Zjednoczonych gospodarką na świecie. Kontrast pomiędzy gwałtownie rozwijającą się ChRL a pogrążoną od dwóch dekad w stagnacji gospodarczej Japonią wyjaśnia, czemu Chiny poczynają sobie coraz śmielej w kontaktach z władzami w Tokio.

28 Saikin no nitchū kankei to Chūgoku jōsei [Niedawne stosunki japońsko-chińskie i sytuacja Chin], Gaimushō Ajia Taiheiyōshūkyoku Chūgoku - Mongoruka, IX 2011, s. 2, http://www.mofa. go.jp/mofaj/area/china/pdfs/kankei.pdf [dostęp 26.12.2011].

29 Sekiyama Takashi, Nitchū no keizai kankei wa kō kawatta. Tai-Chū en shakkan no 30 nen no kiseki [Tak się zmieniły japońsko-chińskie stosunki gospodarcze. 30 lat pożyczki jenowej wobec Chin], Kōbunken, Tokio 2008, s. 13-14.

30 Ibidem, s. 101-128. 


\section{Narzędzia dyplomatyczne}

Chiny często posługiwały się wobec Japonii także szeregiem instrumentów dyplomatycznych. Od czasu historycznej wizyty w Pekinie premiera Tanaki Kakueia w 1972 r. oraz wizyty w Tokio wicepremiera Deng Xiaopinga w 1978 r. oba kraje prowadzą w miarę regularną, choć podatną na zawirowania we wzajemnych stosunkach, wymianę na najwyższym szczeblu. Chiny i Japonia razem należą także do coraz liczniejszych organizacji międzynarodowych, które stanowią wygodne fora służące wymianie poglądów i zacieśnianiu wzajemnej współpracy. Można wśród nich wymienić ASEAN+3, Szczyt Wschodnioazjatycki, Forum Regionalne ASEAN czy APEC. Za kadencji Koizumiego Jun'ichirō spotkania na szczycie niejednokrotnie były dla władz w Pekinie okazją do sygnalizowania niezadowolenia z problemów historycznych. Na przykład na szczycie APEC w Los Cabos w Meksyku w październiku 2002 r. Jiang Zemin nie omieszkał przypomnieć Koizumiemu Jun'ichirō o japońskiej inwazji w czasie II wojny światowej i dać wyraźnie do zrozumienia, że rozwój przyjaznych stosunków bilateralnych nie będzie możliwy w razie kontynuacji przez japońskiego premiera wizyt w świątyni Yasukuni ${ }^{31}$.

Oprócz przysłowiowego „kija” Chiny stosowały wobec Japonii także politykę „marchewki”. Na przykład na spotkaniu w Sankt Petersburgu w maju 2003 r. Hu Jintao zaproponował Koizumiemu Jun'ichirō powołanie do życia Nowego Komitetu Przyjaźni Chińsko-Japońskiej w XXI w., który miał stanowić forum dyskusji na temat problemów w relacjach bilateralnych pomiędzy ludźmi świata nauki, biznesu i polityki z obu krajów. Było to nawiązanie do inicjatywy Nakasone Yasuhiro i Hu Yaobanga z lat 80. XX w. Fakt, że na początku swojej kadencji $\mathrm{Hu}$ Jintao zdecydował się na złagodzenie krytyki wobec Japonii w sprawie problemów historycznych wskazywał na to, iż starał się on skłonić premiera Koizumiego do zaprzestania wizyt w kontrowersyjnej świątyni za pomocą środków budowy wzajemnego zaufania oraz zacieśnienia więzów bilateralnych. O tym, że nowe podejście do władz w Tokio stanowiło element przemyślanej długofalowej strategii nowego rządu może świadczyć to, iż przewodniczącym Nowego Komitetu Przyjaźni Chińsko-Japońskiej w XXI w. został Zheng Bijian - główny teoretyk przewodniczącego ChRL ${ }^{32}$.

Ponieważ, jak już zostało wspomniane przy opisie narzędzi ideologiczno-kulturowych, premier Koizumi nie zrezygnował z wizyt w świątyni Yasukuni, strona chińska zastąpiła nieskuteczną politykę „odwilży” bardziej zdecydowanymi instrumentami dyplomatycznymi. W ostatnim roku rządów Koizumiego,

31 Yomiuri Shinbun Seijibu, Gaikō o kenka ni shita otoko..., s. 247.

32 Shimizu Yoshikazu, Chūgoku ga ,hannichi” o suteru hi [Dzień, w którym Chiny odrzucą „antyjapońskość”], Kōdansha, Tokio 2006, s. 101-151. 
od października 2005 r. do września 2006 r., doszło do całkowitego zawieszenia rozmów na najwyższym szczeblu z władzami w Tokio. Strona chińska odmówiła spotkań z japońskim premierem na szczycie APEC w Korei Południowej w listopadzie 2005 r. oraz na pierwszym Szczycie Azji Wschodniej w Malezji w grudniu 2005 r. Władze w Pekinie unikały także rozmów z ministrem spraw zagranicznych Asō Tarō. Był to wyraz niezadowolenia z jego prawicowych i protajwańskich poglądów. W grudniu 2005 r. Asō powiedział, iż ChRL stanowi zagrożenie dla Japonii ${ }^{33}$, zaś w lutym 2006 r. oświadczył, że Tajwan cieszy się renomą kraju o wysokim poziomie wykształcenia dzięki dawnej kolonialnej polityce władz w Tokio. ChRL zaprotestowała wówczas zarówno przeciw fałszowaniu historii, jak i nazywaniu Tajwanu „krajem”34.

Z drugiej strony, przywództwu KPCh trudno odmówić pewnej elastyczności ideologicznej. Kiedy we wrześniu 2006 r. Koizumi Jun’ichirō przekazał stanowisko szefa rządu Abe Shinzō, chińskie władze i media odczytały to jako szansę na dokonanie przełomu w relacjach wzajemnych. Zdawały się przy tym nie dostrzegać, iż nowy japoński premier ma jeszcze bardziej prawicowe przekonania od swojego poprzednika. Abe był członkiem obozu protajwańskiego, a także zwolennikiem remilitaryzacji Japonii, wprowadzenia do szkół edukacji patriotycznej i wizyt premiera w świątyni Yasukuni ${ }^{35}$. Mimo to Chiny podeszły entuzjastycznie do organizacji pierwszej zagranicznej wizyty nowego premiera Japonii w Pekinie w październiku 2006 r. - zaledwie dwa tygodnie po objęciu przez niego urzędu. Została ona nazwana w ChRL, ,podróżą łamania lodu” (pobing zhi lü). Hu Jintao podkreślił w trakcie spotkania z Abe Shinzō, że wspólnota interesów i przyjaźń chińsko-japońska działa nie tylko na rzecz rozwoju obu krajów, ale również na rzecz pokoju, stabilności oraz dobrobytu Azji i całego świata. Już w kwietniu 2007 r. doszło do rewizyty premiera Wen Jiabao w Tokio, która z kolei doczekała się miana ,podróży topienia lodu” (rongbing zhi lü) ${ }^{36}$. Premier ChRL, jako pierwszy od 22 lat polityk chiński, został zaproszony do wygłoszenia przemowy w japońskim parlamencie. Co istotne, w trakcie wystąpienia Wen Jiabao podziękował Japonii za jej wkład w rozwój gospodarczy i modernizację Chin ${ }^{37}$.

3321 shiji de Zhong-Ri guanxi [Stosunki chińsko-japońskie w XXI w.], pod red. Jin Xide, Chongqing Chubanshe, Chongqing 2007, s. 405.

${ }_{34}$ Nagayama Hideki, Nihon no meiun wa Taiwan ni ari. Gunkaku Chūgoku ga aru Higashi Ajia de [Los Japonii jest na Tajwanie. W Azji Wschodniej ze zbrojącymi się Chinami], Madoka Shuppan, Tokio 2008, s. 227-228.

35 Z drugiej strony w 2006 r. Abe Shinzō nieco złagodził stanowisko w tej sprawie i nie sprecyzował jasno, czy odwiedzi kontrowersyjną świątynię jako premier.

${ }^{36}$ Yan Shengyi, Dangdai Zhongguo waijiao [Dyplomacja współczesnych Chin], Fudan Daxue Chubanshe, Szanghaj 2009, s. 279.

37 Okada Minoru, Nitchū kankei to ODA - tai-Chū ODA o meguru seiji gaikōshi nyūmon [Stosunki japońsko-chińskie a ODA. Wprowadzenie do historii dyplomacji na temat ODA wobec Chin], Nihon Kyōhōsha, Tokio 2008, s. 191. 
Atmosfera odprężenia w stosunkach wzajemnych była kontynuowana za kadencji Fukudy Yasuo, który objął urząd premiera we wrześniu 2007 r. Wizyta premiera Fukudy w Pekinie w grudniu 2007 r. została nazwana ,podróżą powitania wiosny” (yingchun zhi lü). Za kulminację pojednania między rządami obu państw można uznać tzw. podróż ciepłej wiosny (nuanchun zhi lú), kiedy Hu Jintao, jako pierwszy od 10 lat przewodniczący ChRL, odwiedził Tokio w maju 2008 r. ${ }^{38}$ Doszło wówczas do podpisania chińsko-japońskiej wspólnej deklaracji o wszechstronnej promocji strategicznych relacji opartych na wzajemnym poszanowaniu. Oba kraje powtórzyły w niej zapewnienie o pokojowej współpracy i partnerstwie oraz wyrzekły się postrzegania drugiej strony jako zagrożenia. Co ważne, ChRL pozytywnie oceniła japoński wkład w utrzymanie pokoju i stabilności na świecie oraz wyraziła uznanie dla działalności rządu japońskiego w ONZ. Obie strony zgodziły się także, że należy wzmocnić środki budowy wzajemnego zaufania zarówno poprzez regularne wizyty na najwyższym szczeblu, jak i nasilenie wymiany bilateralnej w sferze kultury, edukacji, sportu i turystyki. Nawiązując do inicjatywy Hu Yaobanga z lat 80. XX w., polegającej na zaproszeniu do ChRL 3 tys. reprezentantów japońskiej młodzieży, Hu Jintao i Fukuda Yasuo uzgodnili organizację corocznych wizyt w kraju partnera przez następne cztery lata 4 tys. młodych Chińczyków i Japończyków ${ }^{39}$.

Najbardziej namacalnym osiągnięciem odprężenia w relacjach chińsko-japońskich było podpisanie w czerwcu 2008 r. porozumienia w sprawie wspólnego wydobycia surowców energetycznych na Morzu Wschodniochińskim. Chociaż dotyczyło ono jedynie małego obszaru $\left(2700 \mathrm{~km}^{2}\right)$ i nie regulowało wszystkich szczegółów uczestnictwa japońskich firm w eksploatacji złóż, stanowiło przełom po wieloletnich bezowocnych negocjacjach w tej sprawie. Porozumienie było dowodem na elastyczność władz w Pekinie, które zgodziły się, by strefa wspólnego wydobycia rozciągała się zarówno na wschód, jak i na zachód od mediany, a nie obejmowała jedynie obszary sporne ${ }^{40}$. Ustępstwo strony chińskiej spotkało się jednak z gwałtownymi protestami w kraju. Co ciekawe, władze pozwoliły Chińskiej Pozarządowej Federacji Obrony Wysp Diaoyu na organizację manifestacji przeciwników traktatu przed japońską ambasadą w Pekinie. Chociaż nałożono ograniczenie pod względem liczby uczestników, był to niezwykle rzadki przykład tolerowania bezpośredniej krytyki polityki rządu. Wkrótce zresztą władze ChRL

38 Wizyta Hu Jintao w Japonii do ostatniej chwili pozostawała pod znakiem zapytania z powodu takich problemów w relacjach bilateralnych, które pojawiły się na początku 2008 r., jak seria zatruć w Japonii importowanymi z Chin mrożonkami czy protybetańskie demonstracje w czasie sztafety z ogniem olimpijskim w Japonii. Szerzej na ten temat: Shimizu Yoshikazu, , Chügoku mondai" no..., s. 64-65.

39 Yan Shengyi, Dangdai Zhongguo waijiao..., s. 279-283.

40 J. Manicom, Sino-Japanese Cooperation in the East China Sea: Limitations and Prospects, „Contemporary Southeast Asia” 2008, vol. 30, no. 3, s. 466-469. 
zaczęły odkładać na później rozmowy z Japonią na temat udziału japońskich firm w eksploatacji złoża Chunxiao/Shirakaba ${ }^{41}$. Zachowanie Chin można tłumaczyć presją ze strony środowisk nacjonalistycznych. Japoński dyplomata Yabunaka Mitoji uważa jednak, że nazywanie przez ChRL kwestii wspólnej eksploatacji surowców energetycznych Morza Wschodniochińskiego „delikatną” było zwykłą wymówką w celu utrzymania status quo ${ }^{42}$.

Kiedy we wrześniu 2008 r. Fukudę Yasuo zastąpił na stanowisku premiera Asō Tarō, władze w Pekinie nie przerwały polityki odwilży w stosunkach z Japonią, chociaż jeszcze dwa lata wcześniej odmawiały spotkań z Asō jako ministrem spraw zagranicznych w rządzie Koizumiego. Asō był twórcą niebezpiecznej dla Chin koncepcji ,łuku wolności i dobrobytu”43 oraz zwolennikiem wizyt premiera w świątyni Yasukuni ${ }^{44}$. Mimo to przewodniczący Hu Jintao nie miał obiekcji przeciw przybyciu do Japonii w celu uczestnictwa w szczycie japońsko-chińsko-koreańskim w Fukuoce w grudniu 2008 r. - zaledwie siedem miesięcy po ,podróży ciepłej wiosny”. Fakt, że premier Asō bez problemów złożył rewizytę w ChRL już w kwietniu 2009 r., potwierdził, że chińsko-japońskie kontakty dyplomatyczne na najwyższym szczeblu uległy pełnej normalizacji.

Aby dokonać analizy chińskich narzędzi dyplomatycznych wobec Japonii po 2009 r., warto bliżej przyjrzeć się japońskiej scenie politycznej. Chińska dyplomacja od lat wiele uwagi poświęcała nawiązaniu i utrzymaniu przyjaznych relacji z japońskimi politykami $\mathrm{z}$ różnych ugrupowań. $\mathrm{Z}$ powodu zmarginalizowania się tradycyjnej lewicy w Japonii, po zakończeniu zimnej wojny szczególnie ważne stało się dla KPCh zbudowanie propekińskich frakcji w dwóch największych japońskich partiach konserwatywnych - Partii Liberalno-Demokratycznej (PL-D, Jiyū Minshutō) oraz Partii Demokratycznej (PD, Minshutō). Pierwsza z nich przez długi okres pozostawała ugrupowaniem dominującym, jednak w sierpniu 2009 r. po raz pierwszy w swojej historii przegrała wybory do Izby Reprezentantów i musiała przekazać władzę PD $^{45}$.

Ponieważ PL-D zawsze była stowarzyszeniem frakcji, a nie jednorodną partią, można w niej wyróżnić zarówno skrzydło protajwańskie, jak i propekińskie.

41 Shimizu Yoshikazu, ,Chūgoku mondai” no..., s. 74-75.

42 Yabunaka Mitoji, Kokka no meiun [Los państwa], Shinchōsha, Tokio 2010, s. 149.

43 „Luk wolności i dobrobytu” (jiyū to han'ei no ko) to obszar młodych demokracji od Korei Południowej, poprzez kraje ASEAN, Indie i Turcję, aż po Europę Środkowo-Wschodnią. Według Asō Tarō Japonia powinna w tych państwach wspierać idee wolnego rynku, demokracji i praw człowieka. Szerzej na ten temat: Asō Tarō, Jiyū to han'ei no ko [Łuk wolności i dobrobytu], Gentōsha, Tokio 2008, s. 27-46.

${ }^{44} \mathrm{Z}$ drugiej strony, podobnie jak Abe Shinzō dwa lata wcześniej, Asō Tarō powstrzymał się od wyraźnego stwierdzenia, czy odwiedzi kontrowersyjną świątynię w sierpniu 2009 r. W kwietniu tego roku jedynie wysłał symboliczną ofiarę do Yasukuni.

45 Co prawda po raz pierwszy PL-D utraciła władzę na przełomie 1993 i 1994 roku, ale nadal była wówczas największą partią w parlamencie. 
Z pierwszym z obozów kojarzy się zwłaszcza środowisko wywodzące się z frakcji Kishiego Nobusuke, premiera w latach 1957-1960. Z tej prawicowej grupy, kładącej nacisk na konieczność remilitaryzacji Japonii i rewizji pacyfistycznej konstytucji, pochodzili m.in. premierzy Mori Yoshirō (2000-2001), Koizumi Jun'ichirō (2001-2006), Abe Shinzō (2006-2007) oraz Fukuda Yasuo (2007-2008). Jedynie ostatni z nich mógł być nazwany członkiem obozu propekińskiego - wynika to m.in. z tego, że ojciec Fukudy Yasuo, premier Fukuda Takeo, zawarł w 1978 r. Traktat o pokoju i przyjaźni z ChRL. Za sprzyjające kontaktom z Chinami kontynentalnymi uważano tradycyjnie frakcje założone przez Ikedę Hayato, premiera w latach 1960-1964, oraz Tanakę Kakueia, który jako szef rządu doprowadził do normalizacji chińsko-japońskich stosunków dyplomatycznych w 1972 r. Właśnie z dawnej frakcji Tanaki wywodzą się Nonaka Hiromu i Nikai Toshihiro - dwaj wpływowi politycy PL-D, którzy za rządów premiera Koizumiego bezowocnie starali się promować przyjaźń chińsko-japońską.

Wiele wskazuje na to, że liderzy KPCh przykładają dużą wagę do pielęgnowania osobistych relacji z ludźmi władzy w Japonii. Kiedy w 1992 r. przewodniczący Jiang Zemin złożył wizytę w Tokio z okazji 20-lecia normalizacji bilateralnych stosunków dyplomatycznych, odwiedził także obłożnie chorego byłego premiera Tanakę Kakueia, dziękując za jego wkład w promocję wzajemnych kontaktów. W tym samym roku Tanaka został uroczyście przyjęty w Pekinie przez premiera Li Penga ${ }^{46}$. Chociaż w tym okresie przeciw Tanace Kakueiowi toczył się proces sądowy w związku z aferą korupcyjną Lockheeda, strona chińska nie zapominała o ludziach, którzy, często idąc pod prąd, działali na rzecz porozumienia między władzami w Tokio i Pekinie. Nawet gdy ChRL odmawiała bilateralnych wizyt na wysokim szczeblu za rządów Koizumiego Jun'ichirō, chętnie witała u siebie japońskich polityków kojarzonych z obozem propekińskim. Chociaż na obchody 25. rocznicy podpisania Traktatu o pokoju i przyjaźni w sierpniu 2003 r. nie zaproszono do Pekinu japońskiego szefa rządu, przyjechali na nie byli premierzy Hashimoto Ryūtarō (członek dawnej frakcji Tanaki) oraz Murayama Tomiichi (socjalista, który w 1995 r. oficjalnie przeprosił Chiny za japońskie zbrodnie w czasie II wojny światowej). W uroczystościach symbolicznie wzięli udział również potomkowie głównych autorów Traktatu o pokoju i przyjaźni sprzed 25 lat: syn premiera Fukudy Takeo, ówczesny sekretarz gabinetu Fukuda Yasuo, a także syn ministra spraw zagranicznych Sonody Sunao, poseł Sonoda Hiroyuki ${ }^{47}$.

Podobnie jak PL-D, również PD skupia środowiska różnorodne pod względem ideologii i, co za tym idzie, nastawienia wobec ChRL. Ugrupowanie to

${ }^{46}$ Shimada Masao, Tian Jianong, Sengo nitchū kankei 50-nen - Nitchū sōhō no kadai wa hatasaretaka [50 lat powojennych stosunków japońsko-chińskich. Czy zostały spełnione wzajemne zadania japońsko-chińskie?], Tōhō Shoten, Tokio 1997, s. 421-428.

${ }^{47}$ Fukuda chōkan ga hōchū-Heiwa yūkō jōyaku 25-shūnen, tasaina kaobure, Chūgoku gawa shōtai [Sekretarz gabinetu Fukuda odwiedza Chiny - 25. rocznica Traktatu o pokoju i przyjaźni, różne postacie, zaproszenie ze strony chińskiej], „Nihon Keizai Shinbun”, 10.08.2003, s. 2. 
zrzesza takich prawicowych polityków, jak Maehara Seiji, który uważa Chiny za zagrożenie ${ }^{48}$, oraz licznych członków obozu protajwańskiego - w przeciwieństwie do współpracującej z Guomindangiem PL-D, PD od lat utrzymuje bardzo dobre kontakty z Demokratyczną Partią Postępu (DPP, Minzhu Jinbudang) ${ }^{49}$. Z drugiej strony, do PD należy wielu umiarkowanych działaczy pokroju Hatoyamy Yukio czy Kana Naoto, którzy wywodzą się z lewego skrzydła PL-D lub dawnego obozu socjalistycznego. Nie bez znaczenia jest fakt, że część czołowych członków PD, np. Ozawa Ichirō ${ }^{50}$ czy Watanabe Kōzō, przed opuszczeniem PL-D w 1993 r. należała do propekińskiej frakcji Tanaki. Ozawa Ichirō, przewodniczący PD w latach 2006-2009 oraz jej sekretarz generalny w latach 2009-2010, od lat 80. XX w. uczestniczył w tzw. planie „Wielki Mur”, w ramach którego organizowano imprezy integracyjne polityków PL-D i KPCh. W 2004 r. Ozawa zabrał do Chin ponad stuosobową delegację, w skład której wchodziło kilkunastu młodych parlamentarzystów z $\mathrm{PD}^{51}$.

Po objęciu władzy przez PD Chiny kontynuowały politykę odprężenia w relacjach z Japonią. Przewodniczący Hu Jintao rozmawiał z premierem Hatoyamą Yukio przy okazji Zgromadzenia Ogólnego ONZ w Nowym Jorku już we wrześniu 2009 r., niecały tydzień po objęciu urzędu przez nowego szefa japońskiego rządu. Jak podkreślało Ministerstwo Spraw Zagranicznych Japonii, do spotkania doszło za usilnym naleganiem strony chińskiej ${ }^{52}$. Kolejną okazją do rozmów na najwyższym szczeblu był chińsko-japońsko-koreański szczyt w Pekinie w październiku 2009 r. Premier Hatoyama oświadczył wówczas, że chociaż sojusz z USA nadal stanowi podstawę dyplomacji jego rządu, Japonia w przeszłości ,,była nazbyt uzależniona od Stanów Zjednoczonych" ${ }^{53}$. Nowa postawa władz w Tokio zdawała się stwarzać dla Chin szansę na jeszcze dalej idące zbliżenie w relacjach z Japonią.

W grudniu 2009 r. Hu Jintao przyjął w Pekinie Ozawę Ichirō, który w ramach planu „Wielki Mur” przewodził delegacji liczącej 640 osób, w tym aż 143 posłów partii rządzącej. Przewodniczący ChRL zadał sobie trud, by dać się sfotografować wymieniając uścisk dłoni z każdym japońskim parlamentarzystą z osobna. Inwestowanie przez KPCh w relacje interpersonalne z czołowymi politykami PD

${ }_{48}$ Liu Di, Jiushan Youjifu. Riben Minzhudang zhengzhi de kaimu [Hatoyama Yukio. Początek władzy japońskiej Partii Demokratycznej], Dongfang Chubanshe, Pekin 2009, s. 138.

${ }^{49}$ Honda Yoshihiko, Nitchūtai miezaru kizuna. Chūgoku shunō tsūyaku no mita gaikō hiroku [Niewidzialne więzi japońsko-chińsko-tajwańskie. Tajemny zapis dyplomacji widzianej przez tłumaczy na spotkaniach na szczycie z Chinami], Nihon Keizai Shinbunsha, Tokio 2006, s. 130-131.

50 W lipcu 2012 r. Ozawa opuścił PD, zakładając partię Życie Ludzkie na Pierwszym Miejscu (Kokumin no Seikatsu Ga Daiichi).

51 Ozawa Ichirō, Gōwan ishin [Mocarna odnowa], Kadokawa Gakugei Shuppan, Tokio 2006, s. 140.

52 Minshutō seiken 100 nichi no shinsō [Prawda o 100 dniach rządów Partii Demokratycznej], pod red. Asahi Shinbun Seiken Shuzai Sentā, Asahi Shinbun Shuppan, Tokio 2010, s. 34.

53 Ibidem, s. 113. 
przynosiło wymierne rezultaty. Ozawa z zapałem działał na rzecz zacieśnienia więzów także z młodszym pokoleniem liderów KPCh. Kiedy strona chińska przekazała władzom w Tokio plany wizyty w Japonii wiceprzewodniczącego ChRL Xi Jinpinga pod koniec listopada 2009 r., sekretarz generalny PD użył swoich wpływów, by zmusić Dwór Cesarski do zgody na audiencję chińskiego polityka u cesarza Akihito. Do spotkania Xi Jinpinga z japońskim monarchą rzeczywiście doszło w połowie grudnia 2009 r., jednak PD naraziła się opinii publicznej, ponieważ pogwałciła niepisaną zasadę, zgodnie z którą wszelkie audiencje u cesarza, ze względu na stan jego zdrowia, powinny być ustalane z przynajmniej miesięcznym wyprzedzeniem $^{54}$. Kolejnym wysokim rangą politykiem chińskim, który odwiedził Japonię, był Wen Jiabao w maju 2010 r. Premier ChRL uzgodnił z Hatoyamą Yukio m.in. pogłębienie wymiany kulturalnej między oboma krajami oraz zaprosił tysiąc reprezentantów japońskiej młodzieży na wystawę EXPO w Szanghaju ${ }^{55}$.

Jak już zostało opisane w części poświęconej narzędziom ideologiczno-kulturowym, atmosfera przyjaźni w relacjach chińsko-japońskich została zachwiana na początku rządów premiera Kana Naoto, który objął urząd w czerwcu 2010 r. Incydent na Morzu Wschodniochińskim z września 2010 r., z powodu którego odłożono na później zapowiadaną wizytę tysiąca młodych Japończyków na wystawie EXPO w Szanghaju, pokazał, jak kruche są fundamenty wzajemnej współpracy. Prawdopodobnie nigdy nie dowiemy się, czy zderzenie chińskiego kutra z japońskim okrętem patrolowym było czymś więcej niż zwykłym wypadkiem. W każdym razie w celu wymuszenia na stronie japońskiej uwolnienia kapitana statku władze w Pekinie posłużyły się nie tylko kontrolowanymi protestami antyjapońskimi, ale również szeregiem instrumentów dyplomatycznych. Nie chodzi tu jedynie o całkowite wstrzymanie spotkań na szczycie czy wymiany kulturalnej, ale również o skorzystanie z bardziej radykalnych środków hard power. W drugiej połowie września $2010 \mathrm{r}$. w prowincji Hebei zatrzymano czterech obywateli japońskich, którzy zostali oskarżeni o to, iż w trakcie wyjazdu służbowego filmowali chińskie instalacje wojskowe. Chociaż nie da się wykazać bezpośredniego związku między tym zdarzeniem a aresztowaniem kapitana chińskiego kutra przez Siły Samoobrony, zbieżność czasowa obu wydarzeń zdaje się wskazywać na to, że był to prawdopodobnie środek do wywarcia presji na rząd w Tokio. Tak odczytała to japońska prasa, otwarcie nazywając zatrzymanie japońskich obywateli ,zemstą" ${ }^{\text {"6 }}$. Hipotezę tę zdaje się potwierdzać fakt, że Japończyków, którym za zarzucane im czyny teoretycznie groziła nawet kara

54 Ibidem, s. 226-248.

55 Wen Jiabao tong Riben shouxiang Jiushan Youjifu huitan [Rozmowa Wen Jiabao z japońskim premierem Hatoyamą Yukio], http://www.china-embassy.or.jp/chn/zt/wjbzlfr2010/t705323. htm [dostęp 7.02.2011].

${ }_{56}$ Chūgoku. Nihonjin 4 nin kōsoku. „,Gunji kuiki de satsuei” Shinkasha hōdō. Fujita kankeisha ka [Chiny. Zatrzymanie 4 Japończyków. Informacja Xinhua: „Fotografowali w strefie wojskowej”. Czy związani z Fujitą?], „Yomiuri Shinbun”, 24.11.2010, s. 1. 
śmierci, uwolniono w ciągu zaledwie dwóch tygodni po wypuszczeniu chińskiego kapitana przez stronę japońską.

Szansą na poprawę atmosfery w stosunkach bilateralnych była postawa ChRL po wielkim trzęsieniu ziemi, jakie zdewastowało północno-wschodnie rejony Japonii 11 marca 2011 r. Rząd w Pekinie wyraził solidarność z Japonią i natychmiast wysłał zespoły ratowników do pomocy ofiarom kataklizmu. W maju 2011 r. premier Wen Jiabao odwiedził Japonię, aby wziąć udział w czwartym trójstronnym szczycie japońsko-chińsko-koreańskim. Oprócz obrad w Tokio uczestnicy spotkania pojechali na tereny dotknięte klęską żywiołową, w tym do walczącej z awarią w elektrowni atomowej Fukushimy. Kan Naoto, Wen Jiabao oraz południowokoreański prezydent Lee Myung-bak symbolicznie skosztowali nawet japońskich warzyw, aby podkreślić, że pomimo kryzysu japońskie produkty rolne są bezpieczne dla zdrowia. Premier Wen Jiabao zapowiedział też szybkie zniesienie części ograniczeń w imporcie żywności z Japonii, wprowadzonych po trzęsieniu ziemi. Jak widać, Chiny odeszły od ostrej retoryki i zaczęły ponownie wykorzystywać narzędzia dyplomatyczne kojarzone z soft power.

Przeszkodą w stosunkach bilateralnych okazał się jednak zakup przez Japonię trzech wysp archipelagu Senkaku/Diaoyu we wrześniu 2012 r. Eskalacja napięcia doprowadziła wówczas do zmarnowania okazji do zacieśnienia relacji wzajemnych, jaką miała być obchodzona w tym miesiącu 40. rocznica nawiązania stosunków dyplomatycznych między oboma krajami. ChRL odwołała zaproszenie dla grupy ok. 30 japońskich parlamentarzystów, którzy mieli wziąć udział we wspólnych uroczystościach w Pekinie ${ }^{57}$. Takie ciągłe przeplatanie przez ChRL polityki eskalacji napięcia oraz ,odwilży” w relacjach z Japonią utrudnia stworzenie stosunków opartych na prawdziwym zaufaniu między tymi krajami.

\section{Narzędzia wojskowe}

W oficjalnej strategii obronnej Chiny nieustannie podkreślały, że nie dążą do hegemonii w regionie i pragną rozwijać współpracę w dziedzinie bezpieczeństwa z krajami sąsiednimi, w tym z Japonią. W Białej księdze, dotyczącej obrony narodowej w 2006 r., władze ChRL dały jednak wyraz swoim obawom odnośnie do remilitaryzacji Japonii. Wśród narastających problemów w regionie Azji-Pacyfiku zauważyły, że „Stany Zjednoczone wzmacniają sojusz wojskowy [z Japonią] oraz promują wojskową integrację. Japonia pragnie dokonać rewizji pacyfistycznej konstytucji i wcielić w życie samoobronę zbiorową, oczywista jest też tendencja

${ }^{57}$ Nicchū kokkō seijōka 40 shūnen. Chōtōha giindan hōchū chūshi ni [40. rocznica normalizacji stosunków dyplomatycznych. Odwołanie wizyty w Chinach ponadpartyjnej grupy parlamentarzystów], „Mainichi Shinbun”, 13.09.2012, s. 2. 
do zorientowania jej postawy militarnej na zewnątrz" ${ }^{58}$. Z kolei niepokój Tokio budzi to, że Pekin stale zwiększa wydatki na zbrojenia. Rząd japoński obawia się zachwiania równowagi potencjałów militarnych $\mathrm{w}$ regionie. O coraz większej asertywności Chin może świadczyć nasilenie aktywności chińskich okrętów wojennych i statków badawczych na Morzu Wschodniochińskim pod koniec lat 90. XX w. Po przejęciu władzy w Japonii przez PD powstały sprzyjające uwarunkowania do zacieśnienia obustronnej współpracy w dziedzinie bezpieczeństwa, jednak Chiny nie złagodziły stanowiska w takich kwestiach jak spór terytorialny o wyspy Senkaku/Diaoyu.

Prowokacyjne naruszenia japońskich wód przez statki badawcze i okręty chińskiej marynarki wojennej pokazują, że ChRL nie stroni od twardej polityki wobec swojego sąsiada. Problem chińskich badań naukowych na Morzu Wschodniochińskim nasilił się w drugiej połowie lat 90 . XX w. Władze w Pekinie zleciły wówczas poszukiwanie na dnie pod spornymi wodami surowców energetycznych, potrzebnych dla gospodarki szybko rozwijającego się kraju. Okręty ChRL wpłynęły na tereny, do których prawo przypisuje sobie Japonia, 16 razy w 1998 r., 30 razy w 1999 r. (w tym czterokrotnie na wody wokół spornych z Japonią wysp Senkaku/Diaoyu) i 24 razy w 2000 r. Ich załogi kontynuowały badania, w tym magnetyczne i sejsmiczne, pomimo wezwań Japońskiej Morskiej Agencji Obrony do opuszczenia spornego obszaru ${ }^{59}$.

Chińskie badania naukowe na Morzu Wschodniochińskim służyły nie tylko dokładniejszemu określeniu miejsc występowania złóż zasobów naturalnych, ale również miały związek z niezwykle delikatną dla każdego kraju kwestią obrony narodowej. Chociaż Konwencja o prawie morza z Montego Bay z 1982 r. nie zakazuje explicite ruchu okrętów wojennych czy samolotów szpiegowskich w cudzej wyłącznej strefie ekonomicznej, państwo nadbrzeżne może twierdzić, że z wolności nawigacji i przelotu należy korzystać tylko w celach pokojowych. Za takie zaś trudno uznać zbieranie danych dotyczących ukształtowania dna, głębokości, temperatury wody czy prądów morskich, gdyż mogą one służyć chociażby przeprowadzaniu operacji marynarki wojennej przy użyciu łodzi podwodnych. Poza tym chińskie okręty wpływały na japońskie wody prawdopodobnie także w celach szkoleniowych i szpiegowskich, zbierając za pomocą środków elektronicznych dane na temat posunięć japońskich Sił Samoobrony i armii Stanów Zjednoczonych stacjonującej na Okinawie. Na dodatek działania tego typu mogły mieć za zadanie sprawdzenie reakcji wojsk i władz japońskich na sytuacje kryzysowe ${ }^{60}$. Szczególnie istotne było dla Chin rozeznanie wód w okolicach Tajwanu.

582006 nian Zhongguo de guofang baipishu (quanwen) [Biała księga obrony narodowej Chin w 2006 roku (pełen tekst)], http://big5.xinhuanet.com/gate/big5/news.xinhuanet.com/mil/200612/29/content_5546516.htm [dostęp 22.04.2011].

59 M.J.Valencia, Yoshihisa Amae, Regime Building in the East China Sea, „Ocean Development \& International Law" 2003, vol. 34, no. 2, s. 196-198.

60 Ibidem, s. 200-203. 
Co więcej, równocześnie wzrastała liczba naruszeń japońskiej wyłącznej strefy ekonomicznej przez chińskie jednostki wojskowe. W sierpniu 1995 r. ChRL wysłała w okolice wysp Senkaku/Diaoyu kilka myśliwców, które zawróciły dopiero po próbie ich przechwycenia przez dwa japońskie odrzutowce z Okinawy $^{61}$. W maju 1999 r. $110 \mathrm{~km}$ na północ od wysp Senkaku/Diaoyu zauważono aż 12 chińskich okrętów, zaś w połowie lipca 1999 r. 130-260 km na północ od spornego archipelagu dostrzeżono 10 okrętów, w tym trzy niszczyciele klasy Luda I. Z kolei bardzo rozległą obserwację przeprowadził okręt „Haibing-723”, który w maju 2000 r. okrążył wyspy Honsiu, Sikoku i Kiusiu, by zakończyć misję na Morzu Wschodniochińskim, a także okręt „Dongtiao-232”, krążący w lipcu 2000 r. po północnej części tego akwenu oraz wzdłuż wybrzeża Japonii na wschód od wysp Riukiu ${ }^{62}$.

Powtarzające się incydenty spowodowały ochłodzenie stosunków chińsko-japońskich. W 2000 r. w Japonii podniosły się głosy polityków pragnących zmusić ChRL do zaprzestania badań na wschód od mediany, wykorzystując do tego wstrzymanie pomocy gospodarczej dla Pekinu. Rzeczywiście w sierpniu $2000 \mathrm{r}$. władze w Tokio zawiesiły wypłatę dwóch pożyczek wartych 17,2 mld jenów. Japońska dyplomacja okazała się skuteczna, gdyż wkrótce zapowiedziano rozpoczęcie negocjacji w sprawie badań dna Morza Wschodniochińskiego ${ }^{63}$. W październiku tego roku premier Zhu Rongji obiecał zmniejszyć natężenie badań dna morskiego w pobliżu Japonii ${ }^{64}$, w odpowiedzi na co Japonia odblokowała pożyczki dla Chin $^{65}$. Ostatecznie porozumienie zawarto w lutym $2001 \mathrm{r}$. Zgodnie z jego postanowieniami Chiny mają z dwumiesięcznym wyprzedzeniem informować Japonię o planowanym wpłynięciu statków badawczych na wody „w pobliżu Japonii i będące w sferze zainteresowania Japonii”. Analogicznie ma się zachowywać Tokio w odniesieniu do badań prowadzonych blisko wybrzeża chińskiego. Układ nie spowodował jednak nagłego ocieplenia w stosunkach chińsko-japońskich, ponieważ rząd w Pekinie traktował go jako sposób na uzyskanie automatycznej zgody władz w Tokio na poszczególne badania i często nie stosował się do podanych Japonii planów działań na Morzu Wschodniochińskim ${ }^{66}$.

Kolejne ochłodzenie $\mathrm{w}$ stosunkach między oboma krajami spowodował kryzys związany z rozpoczęciem w 2003 r. eksploatacji złoża surowców energetycznych Chunxiao/Shirakaba. Równocześnie z budową tej kontrowersyjnej

${ }_{61}$ V.A. Pace, The U.S.-Japan Security Alliance and the PRC. The Abandonment-Entrapment Dynamic, the Balance of Threat and National Identity in the Trilateral Relationship, http://www. vincentpace.info/thesis/senkaku_islands_crisis.html [dostęp 30.04.2011].

62 M.J. Valencia, Yoshihisa Amae, op. cit., s. 202.

${ }_{63}$ T. Takamine, A New Dynamism in Sino-Japanese Security Relations: Japan's Strategic Use of Foreign Aid, „The Pacific Review” 2005, vol. 18, no. 4, s. 455.

${ }_{64}$ M.J. Valencia, Yoshihisa Amae, op. cit., s. 198.

65 T. Takamine, op. cit., s. 455.

66 Ibidem, s. 456. 
platformy wiertniczej nie ustawała intensyfikacja działań chińskiej marynarki na japońskich wodach terytorialnych. W listopadzie 2003 r. chiński okręt podwodny klasy Min po raz pierwszy przepłynął przez cieśninę Ōsumi pomiędzy Kiusiu a wyspami Riukiu ${ }^{67}$. Na dodatek w 2004 r. ChRL nasiliła poszukiwania dna morskiego w okolicach Okinotori, należącej do Japonii skały wystającej ponad poziom morza w regionie o istotnym znaczeniu strategicznym - między Tajwanem a amerykańską wyspą Guam. Podczas gdy rząd w Tokio uważał Okinotori za wyspę, strona chińska odmawiała jej tego statusu, kwestionując też prawo Japonii do wyznaczenia wokół niej wyłącznej strefy ekonomicznej. Władze japońskie obawiały się, że chińskie badania miały służyć lepszemu poznaniu tego obszaru w razie konfliktu z Tajwanem i Stanami Zjednoczonymi ${ }^{6}$.

Coraz większa liczba incydentów na Morzu Wschodniochińskim skłoniła Japońską Agencję Obrony do rewizji narodowej strategii obronnej. W dniu 9 listopada 2004 r. ogłoszono trzy scenariusze, według których ChRL mogłaby zaatakować Japonię. Jeden z nich przewidywał spór o zasoby naturalne Morza Wschodniochińskiego, drugi roszczenia do wysp Senkaku/Diaoyu, zaś trzeci starcie w związku z agresją na Tajwan ${ }^{69}$. Reakcja ChRL była natychmiastowa. Rzeczniczka prasowa chińskiego MSZ, Zhang Qiyue, zdecydowanie zaprotestowała, mówiąc, że takie „hipotezy są bezpodstawne i nie do pojęcia"70. Na dodatek następnego dnia w pobliżu należącego do wysp Riukiu archipelagu Miyako pojawił się niezidentyfikowany okręt podwodny. Jego załoga nie odpowiedziała na wezwania japońskich Sił Samoobrony do wynurzenia i wywieszenia bandery, jak tego wymaga prawo morza. Zmusiło to premiera Koizumiego Jun'ichirō do wprowadzenia po raz drugi w powojennej historii Japonii stanu alarmowego dla marynarki ${ }^{71}$. W dniu 12 listopada 2004 r. strona japońska ustaliła, że ma do czynienia z chińskim atomowym okrętem podwodnym klasy Han i złożyła oficjalny protest wobec rządu w Pekinie ${ }^{72}$. Pochodzenie okrętu zostało ostatecznie potwierdzone

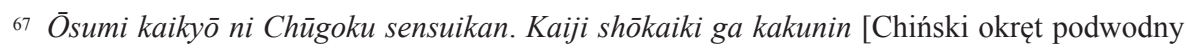
w cieśninie Ōsumi. Samolot patrolowy morskich Sił Samoobrony potwierdza], „Yomiuri Shinbun”, wydanie z Zachodniej Japonii, 13.11.2003, s. 30.

${ }^{6}$ Okinotori tōtotsu ni ,,iwa da” to shuchō shi hajimeta Chūgoku [Chiny nagle zaczęły twierdzić, że Okinotori ,jest skałą”], „Yomiuri Shinbun”, 30.04.2004, s. 3.

${ }^{69}$ Defense Strategists Look to China's Attack Threat, http://www.japantimes.co.jp/cgi-bin/ getarticle.pl5?nn20041109f3.htm [dostęp 10.11.2012].

70 FM: „China attack” Hypes in Japanese Media Baseless, news.xinhuanet.com/english/ 2004-11/10/content_2198659.htm [dostęp 10.11.2012].

${ }_{11}$ Chūgoku? Sensuikan ga ryōkai shinpan. Okinawa kaiiki, kaijō keibi kōdō o hatsurei. „Kōsakusen" irai 2 dome [Chiny? Okręt podwodny narusza wody terytorialne. Obszar wód Okinawy, wprowadzenie stanu alarmowego na morzu. Drugi raz od czasu „statku szpiegowskiego”], „Yomiuri Shinbun", 10.11.2004, s. 1.

72 Sensuikan ryōkai shinpan. Taichū, kibishii yoron haikei. Seifu kōgi ni yotō, kajō hairyo to hihan [Naruszenie wód terytorialnych przez okręt podwodny. W tle surowe zdanie opinii publicznej wobec Chin. Opozycja krytykuje protest rządu za nadmierną spolegliwość], „Yomiuri Shinbun”, 13.11.2004, s. 3 . 
16 listopada 2004 r., gdy wpłynął on do bazy chińskiej marynarki Jianggezhuang w pobliżu Qingdao ${ }^{73}$. Dopiero wtedy władze chińskie przyznały, że to ich okręt zabłąkał się na japońskie wody, przy czym podały do wiadomości, iż uczynił to z powodu „technicznej usterki w trakcie regularnych ćwiczeń”. Wyraziły także „żal” z tego powodu ${ }^{74}$. Rząd w Tokio nie naciskał na wyraźniejsze przeprosiny, ale eksperci japońscy nie kryli wątpliwości, czy okręt, który przez kilka dni manewrował pod wodą w trudnym, płytkim akwenie, mógł być rzeczywiście niesprawny technicznie ${ }^{75}$.

Nie wiadomo na pewno, czy incydent miał związek ze zmianą japońskiej strategii obronnej, ale bez wątpienia spowodował dalszy spadek zaufania we wzajemnych stosunkach. Na dodatek w styczniu 2005 r. Japońska Agencja Obrony ostatecznie przygotowała plan obrony terytorium stycznego z Morzem Wschodniochińskim. Przewidywał on przemieszczenie w te rejony 55 tys. żołnierzy, a także okrętów wojennych, łodzi podwodnych i myśliwców w razie ataku z zewnątrz. Położono przy tym nacisk na wzmocnienie systemu wczesnego ostrzegania i przygotowanie do szybkiego odbicia odległych wysepek za pomoca wyspecjalizowanych oddziałów desantowych ${ }^{76}$. Chociaż plan ten można postrzegać jako część szerszej relokacji wojsk, związanej z przesunięciem po upadku ZSRR akcentu z obrony północnych na południowe rubieże kraju, data jego wydania wskazuje na bezpośredni związek z chęcią powstrzymania ekspansywnych działań ChRL na spornym terenie.

W 2005 r. intensyfikacja działań Chińskiej Armii Ludowo-Wyzwoleńczej na Morzu Wschodniochińskim osiągnęła punkt kulminacyjny. Siły Samoobrony musiały wysyłać nadzwyczajne patrole myśliwców z powodu podejrzeń naruszenia japońskich wód terytorialnych i przestrzeni powietrznej aż 107 razy - ośmiokrotnie więcej niż rok wcześniej ${ }^{77}$. Sytuacja zaostrzyła się szczególnie wczesną jesienią

73 Ryōkai shinpan no gensen, Chūgoku nyūkō o kakunin [Potwierdzenie, że atomowy okręt podwodny, który naruszył wody terytorialne, wpłynął do chińskiego portu], „Yomiuri Shinbun”, 16.11.2004, s. 1 .

${ }_{74}$ Sensuikan ryōkai shinpan. Chūgoku, jikoku gensen to mitomeru. Kunrenchū ,ayamatte shinpan, ikan” [Naruszenie wód terytorialnych przez okręt podwodny. Chiny potwierdzają, że to ich atomowy okręt podwodny. W trakcie ćwiczeń „,wtargnął przez błąd, żałujemy”], „Yomiuri Shinbun", 17.11.2004, s. 1.

${ }^{75}$ Chūgoku gensen ryōkai shinpan, Seifu, fukaoi sake, ,gaikō kādo” ni [Naruszenie wód terytorialnych przez chiński atomowy okręt podwodny. Rząd unika głębszych dochodzeń, ku „dyplomatycznej karcie”], „Yomiuri Shinbun”, 17.11.2004, s. 2.

${ }^{6}$ Defense Plan Prepared for Remote Islands, http://www.japantimes.co.jp/cgi-bin/getarticle. p15?nn20050116a2.htm [dostęp 14.02.2005].

77 Jieitai-Chūgokugun hottorain. Aki no gōi mezasu. Kansen ya kōkūki no gūhatsu shōtotsu o kaihi [Gorąca linia między Siłami Samoobrony a armią chińską. Ku porozumieniu na jesieni. Uniknięcie przypadkowego zderzenia okrętów lub samolotów], „Yomiuri Shinbun”, 16.04.2007, s. 1. 
2005 r., kiedy ChRL wysłała całą flotyllę okrętów wojennych do obrony platformy wiertniczej Chunxiao/Shirakaba. Niektóre z chińskich niszczycieli demonstracyjnie mierzyły z dział na przepływające w pobliżu jednostki Sił Samoobrony ${ }^{78}$. Liczne incydenty na japońskich wodach terytorialnych pokazały, że Chiny nie stronią od użycia sił zbrojnych jako środka wywierania presji na Japonię.

Sprzyjająca atmosfera do zacieśnienia współpracy w dziedzinie obronności między Chinami i Japonią powstała dopiero po ustąpieniu w 2006 r. premiera Koizumiego Jun'ichirō. W kwietniu 2007 r. premierzy Wen Jiabao i Abe Shinzō zgodzili się ustanowić specjalną „gorącą linię" pomiędzy resortami obrony obu krajów ${ }^{79}$. W sierpniu 2007 r., przy okazji pierwszej od dziewięciu lat wizyty w Japonii chińskiego ministra obrony, Chiny i Japonia zgodziły się na wzajemne ugoszczenie w swoich portach okrętów wojennych drugiej strony. W ramach tej wymiany do Zatoki Tokijskiej w listopadzie 2007 r. zawinął chiński niszczyciel rakietowy. Przygotowanie wizyty okrętu Sił Samoobrony w Chinach zajęło więcej czasu ze względu na wciąż żywą pamięć o japońskich zbrodniach z czasów II wojny światowej. Punktem przełomowym mogła być zgoda władz w Pekinie pod koniec maja 2008 r. na lądowanie w Chinach samolotów Sił Samoobrony w celu dostarczenia zaopatrzenia dla ofiar trzęsienia ziemi w Syczuanie ${ }^{80}$. Niestety, z powodu fali gwałtownych protestów w chińskim Internecie władze w Pekinie w ostatniej chwili poprosiły stronę japońską o wstrzymanie się z udzieleniem pomocy $\mathrm{w}$ tej formie ${ }^{81}$. W czerwcu $2008 \mathrm{r}$. do portu $\mathrm{w}$ Zhanjiang $\mathrm{w}$ prowincji Guangdong zawinął natomiast japoński okręt „Sazanami”, który przywiózł koce, żywność i lekarstwa. Było to pierwszy w historii okręt Sił Samoobrony, jaki odwiedził $\mathrm{ChRL}^{82}$.

Kiedy we wrześniu 2009 r. został powołany rząd PD z premierem Hatoyamą Yukio na czele, powstały bardzo sprzyjające warunki do pogłębienia chińsko-japońskiej współpracy w dziedzinie polityki bezpieczeństwa. Nowa japońska partia rządząca skupiała wielu umiarkowanych polityków, którzy dążyli do położenia większego nacisku raczej na relacje z państwami ościennymi niż z sojuszniczymi Stanami Zjednoczonymi. W listopadzie 2009 r. Japonię odwiedził chiński minister obrony Liang Guanglie, który uzgodnił ze swoim japońskim odpowiednikiem Kitazawą Toshimim, iż oba kraje będą dalej rozwijać współ-

78 J. Manicom, op. cit., s. 462-463.

79 Jieitai-Chügokugun hottorain..., s. 1.

${ }^{80}$ Chūgoku Shisen daijishin Küjiki haken, makoto no kyōryoku e ashigakari [Wysłanie samolotów Powietrznych Sił Samoobrony do wielkiego trzęsienia ziemi w chińskim Syczuanie, krok ku prawdziwej współpracy], „Yomiuri Shinbun”, 29.05.2008, s. 3.

81 Shimizu Yoshikazu, ,Chūgoku mondai” no..., s. 72-73.

82 Jieeikan hōchū. Gunji no tōmeisei kōjō ni tsunageyo [Odwiedziny w Chinach okrętu Sił Samoobrony. Niechaj się przyczynią do podniesienia transparentności armii], „Yomiuri Shinbun”, 1.07.2008, s. 3 . 
pracę w dziedzinie bezpieczeństwa, a nawet zorganizują w 2010 r. wspólne ćwiczenia marynarki ${ }^{83}$.

Japonię nadal niepokoił jednak wzrost aktywności chińskiej marynarki. Na przykład w kwietniu 2010 r. zaobserwowano aż 10 okrętów, w tym dwa podwodne, które przepłynęły między wyspami Okinawa i Miyako w celu odbycia ćwiczeń na Oceanie Spokojnym ${ }^{84}$. Na dodatek wchodzący w skład floty chiński helikopter dwukrotnie zbliżył się na wyzywająco niebezpieczną odległość do okrętu japońskich Sił Samoobrony, co wywołało protest władz w Tokio ${ }^{85}$. Znacznie poważniejszy okazał się incydent na Morzu Wschodniochińskim z września 2010 r. Oprócz zawieszenia wymiany kulturalnej i spotkań na szczycie, ChRL zamroziła wówczas również współpracę z Japonią w dziedzinie bezpieczeństwa. Przykładowo w połowie października 2010 r. Chiny odwołały wizytę w porcie Qingdao floty okrętów Sił Samoobrony, która odbywała ćwiczenia w nawigacji na dalekim morzu ${ }^{86}$. Co prawda, w grudniu 2011 r. do portu Qingdao zawiną japoński okręt „Kirisame”, jednak dyskurs na temat zakupu przez Japonię trzech wysp Senkaku/Diaoyu doprowadził do ponownego zamrożenia wymiany wojskowej w następnym roku. Jednocześnie od czasu incydentu z 2010 r. znacząco wzrosła liczba naruszeń japońskich wód przez chińskie statki badawcze i okręty patrolowe ${ }^{87}$.

Jak widać, ChRL nie stroniła od używania narzędzi militarnych w relacjach nawet $\mathrm{z}$ tak potężnym państwem jak Japonia. Wielokrotne lekceważenie żądań władz w Tokio, by zaprzestać łamania prawa morza, jest dowodem na rosnącą asertywność Chin na arenie międzynarodowej. Z drugiej strony, skuteczność tych działań wydaje się wątpliwa. Naruszanie wód terytorialnych Japonii przez chińskie okręty spotkało się z ostrym potępieniem zarówno przez rząd w Tokio, jak i przez japońskie partie opozycyjne. Liczne incydenty doprowadziły jedynie do spadku zaufania wobec Pekinu, czasowego wstrzymania pożyczek w jenach w ramach

${ }^{83}$ Zhong-Ri fangwu bumen lianhe xinwen gongbao [Wspólne oświadczenie prasowe ministerstw obrony Chin i Japonii], http://news.xinhuanet.com/world/2009-11/27/content_12552386. htm [dostęp 16.01.2011].

${ }^{84}$ Chūgoku kantai Okinawa kinkai o nanka. Taiheiyō de enshū ka. Sensuikan fukumu 10 seki [Chińska flota przepływa na południe od Okinawy. Czyżby ćwiczenia na Pacyfiku? 10 okrętów, w tym podwodne], „Yomiuri Shinbun”, 13.04.2010, s. 2.

${ }_{85}$ Chūgoku heri mata Kaiji goeikan ni ijō sekkin. Gaimushō ga kōgi [Chiński helikopter znowu nadzwyczajnie zbliża się do okrętu patrolowego Sił Samoobrony. Ministerstwo Spraw Zagranicznych protestuje], ,Yomiuri Shinbun”, 22.04.2010, s. 2.

${ }^{86}$ Kaiji renshū kantai no Chūgoku kikōo o chūshi enki yōsei o uke [Otrzymanie przez ćwiczebną flotę Sił Samoobrony prośby wstrzymania i odłożenia wpłynięcia do chińskiego portu], „Yomiuri Shinbun", 15.10.2010, s. 2.

${ }^{87}$ Takahara Akio, Itō Tsuyoshi, Minshutō seiken tanjō ikō no Nicchū kankei [Relacje japońsko-chińskie od rozpoczęcia rządów Partii Demokratycznej], [w:] Nicchū kankeishi 1972-2012, I Seiji [Historia stosunków japońsko-chińskich 1972-2012, I: Polityka], pod red. Takahary Akio i Hattoriego Ryūjiego, Tōkyō Daigaku Shuppankai, Tokio 2012, s. 496-497. 
pomocy rozwojowej oraz przyspieszenia przez Japonię prac nad wzmocnieniem obrony archipelagu Riukiu. Podobnie jak w przypadku kooperacji w innych dziedzinach, na współpracę chińsko-japońską w sferze obronności olbrzymi wpływ wywarły uwarunkowania historyczne. Władze w Pekinie hamowały rozwój współpracy w polityce bezpieczeństwa z Japonią, powołując się na antyjapońskie uprzedzenia po zbrodniach z czasów II wojny światowej.

\section{Podsumowanie}

Celem chińskiej dyplomacji w kontaktach z Japonią za rządów Hu Jintao było utrzymanie stabilnej współpracy, zwłaszcza w dziedzinie gospodarczej, przy jednoczesnej zdecydowanej obronie własnego stanowiska w kwestiach spornych. ChRL umiejętnie posługiwała się narzędziami charakterystycznymi zarówno dla soft power, jak i hard power, często rezygnując z jednych na rzecz drugich, gdy tylko pierwsze okazały się nieskuteczne. W ten sposób można wytłumaczyć przejście z łagodnej postawy wobec Japonii na początku rządów Hu Jintao do bardziej zdecydowanej polityki pod koniec kadencji premiera Koizumiego i z powrotem do aktywnej promocji „odwilży” po objęciu władzy przez Abe Shinzō.

Spośród wszystkich instrumentów wykorzystywanych przez ChRL w polityce wobec Japonii najbardziej charakterystyczne pozostają narzędzia ideologiczno-kulturowe. Problemy historyczne niejednokrotnie ograniczały możliwości swobodnego formułowania przez władze w Pekinie strategii dyplomatycznej wobec Japonii. Chociaż na początku swojej kadencji przewodniczący Hu Jintao dążył do ocieplenia stosunków z sąsiadem, musiał zaostrzyć kurs wobec władz w Tokio z powodu kolejnych wizyt premiera Koizumiego w świątyni Yasukuni. $\mathrm{Z}$ drugiej strony, problemy historyczne często wypływały na światło dzienne bez prowokacji ze strony rządu japońskiego, stając się wygodnym instrumentem wywierania nacisku na władze w Tokio w sprawach, które nie miały bezpośredniego związku z trudną historią obu krajów.

Skuteczność narzędzi stosowanych przez Chiny w stosunkach z Japonią była jednak ograniczona. Pomimo wywierania silnej presji na rząd w Tokio, władzom w Pekinie nie udało się skłonić premiera Koizumiego do rezygnacji z wizyt w świątyni Yasukuni i dopiero jego następcy okazali się bardziej skłonni do współpracy w tej sprawie. Polityka „odwilży” w relacjach wzajemnych po 2006 r. zdawała się już przynosić pierwsze owoce w postaci zacieśnienia współpracy bilateralnej, gdy doszło do dalszej eskalacji napięcia we wrześniu 2010 r. i sierpniu 2012 r. Incydenty na Morzu Wschodniochińskim pokazały, że w obronie swoich interesów narodowych Chiny bez skrupułów sięgają po całą gamę narzędzi z zakresu hard power. Wiele wskazuje na to, że w celu skłonienia Japonii do uwolnienia 
kapitana kutra rybackiego w 2010 r. strona chińska posłużyła się instrumentami ideologiczno-kulturowymi (ciche przyzwolenie na demonstracje antyjapońskie), ekonomicznymi (wstrzymanie eksportu metali ziem rzadkich do Japonii), dyplomatycznymi (zawieszenie rozmów na najwyższym szczeblu z władzami w Tokio, aresztowanie czterech obywateli japońskich), a nawet w pewnym sensie wojskowymi (odwołanie wizyty okrętów Sił Samoobrony w chińskim porcie). Chociaż polityka ta zakończyła się krótkoterminowym sukcesem - Japonia uwolniła chińskiego kapitana - działanie z pozycji siły tak naprawdę może przynieść ChRL więcej szkody niż korzyści. Nadmierne wykorzystywanie instrumentów hard power umacnia jedynie wizerunek Chin jako państwa nieobliczalnego i stanowiącego zagrożenie dla Japonii, co z kolei osłabia pozycję środowisk propekińskich na japońskiej scenie politycznej. 